\title{
PLANT EVOLUTION IN MEDITERRANEAN CLIMATE ZONES
}

\section{IOPB Symposium: Plant Evolution in Mediterranean Climate Zones}

\author{
Gonzalo Nieto Feliner ${ }^{1}$, Pilar Catalán ${ }^{2}$, Jaime Güemes ${ }^{3}$ \& Josep A. Rosselló ${ }^{3}$ \\ ${ }^{1}$ Real Jardín Botánico, CSIC, Plaza de Murillo 2, 28014 Madrid, Spain.nieto@ma-rjb.csic.es \\ 2 Department of Agriculture (Botany), University of Zaragoza, 50013 Zaragoza, Spain. pcatalan@unizar.es \\ ${ }^{3}$ Jardi Botànic, Universidad de Valencia, c/Quart 80, E-46008 Valencia, Spain. jaime.guemes@uv.es, \\ josep.rossello@uv.es
}

Mediterranean biodiversity richness is well recognized and attributed to a combination of factors (Médail \& Quézel, 1997). Paleoclimatic changes have been documented for the last 5-10 million years including the establishment of a summer drought that represents the onset of a mediterranean climate (Suc, 1984). Two main climatic events have been invoked to explain almost every distribution pattern in the Mediterranean: the Messinian salinity crisis (Bocquet \& al., 1978) and Pleistocene glaciations (Hewitt, 1996; Peyron \& al., 1998). Paleogeological events are determinant factors for diversity in this region both through their influence on climate changes as well as by creating land-mass connections resulting from tectonic dynamics or sea-level oscillations due to eustatic changes (Rögl \& Steininger, 1984). The patchy nature of the current landscape, which hosts a diversity of habitats in a limited space, has also played a role in Mediterranean diversity by providing an arena for differentiation in partially isolated niches and ecotones. Human influence during the Pleistocene could have also contributed to the floristic richness by generating disturbed habitats suitable for hybridization. However, a negative effect is likely as well, although we lack precise data for estimating rates of species extinction in the Mediterranean due to anthropogenic causes (Greuter, 1994).

Many data on Mediterranean plants exist that cover different aspects relating to plant evolution (Thompson, 2005). However, much more basic empirical work is needed to continue to understand how plant groups reacted to the climatic, geologic and ecological changes that occurred along the last few million years within this basin and how those changes affected their diversification and evolution. These standing questions have stimulated symposia (e.g., Phylogeography in Southern European Refugia, Vairao, Portugal, Mar 2002) as well as ongoing projects, focusing on areas and biotic connections within the region such as the Tyrrhenian or the westernmost Europe-Africa bridge (Gibraltar).

In May 2004, the IX ${ }^{\text {th }}$ Meeting of the International Organization of Plant Biosystematists (IOPB) was held in Valencia organized by the authors of this introduction, and sponsored by the Universities of Valencia and Zaragoza, the Consejo Superior de Investigaciones Científicas (CSIC), the Spanish Ministry of Science and Education, and the International Association for Plant Taxonomy (Comes, 2004; Stuessy, 2004; http://www. jardibotanic.org/iopb.html). The topic of the meeting was Plant Evolution in the Mediterranean Climate Zones, and it was addressed through several approaches, which the organizers arranged into the following symposia: biogeography and phylogeography, conservation and genetic diversity, systematics and phylogeny, ecological factors in speciation, speciation models, and comparisons among the Mediterranean areas of the world. There were twelve invited lectures, plus 43 oral communications and some 91 posters. Although all five regions with Mediterranean climate (Australia, California, Cape Region, Chile, Mediterranean Basin) were considered, a majority of the papers were devoted to the Mediterranean Basin itself. A selection of eleven of the papers presented during the meeting is published within this issue of Taxon.

The first four papers are mostly devoted to phylogeographic and biogeographic topics. In searching for phylogeographic patterns along the Mediterranean, Kadereit \& al. (p. 861) use a spatially simplified system, i.e., species restricted to coastal habitats and thus with linear ranges. They found similarities in the partitioning of genetic diversity across the five coastal species studied, including more consistency among Eastern patterns presumably due to a lesser impact of Pleistocene climatic changes as well as to the occurrence of isolating seacurrents in that area. Based on the large amount of data gathered by his team, Petit \& al. (p. 877) provide an essay on tree and shrub diversity in the context of climatic change. They discuss the currently rich genetic diversity of Mediterranean species as product of the biogeographic history of the area, and especially on climatic changes. Diadema \& al. (p. 887) use ITS sequence data, which reveal a geographical structure across the range of a maritime alpine endemic species, together with topography and paleoclimatic data to reconstruct 
evolutionary history, and in particular, to locate Pleistocene refugia in the southern part of the Maritime and Ligurian Alps. Carine (p. 897) uses an ITS phylogeny of Convolvulus to test a biogeographic hypothesis on relationships between Macaronesian species and their continental relatives. He discusses the scarcity of patterns in island biogeography due to the stochastic nature of evolution.

Fady-Welterlen (p. 905) presents a comparative study on Mediterranean conifers, using data from the literature as well as from his own works, to examine biodiversity in the Mediterranean basin at the infraspecific level. He concluded that genetic diversity within species was higher than expected in most Mediterranean tree species and populations, and that Eastern Mediterranean conifers are genetically more diverse than Western ones.

The next three papers present phylogenies of groups that have undergone diversification in the Mediterranean. Paun \& al. (p. 909) draw a number of conclusions from their phylogeny of Ranunculus and molecular clock analysis, including identification of ecological and geographical clades, and the independent multiple evolution of annuals and geophytes. Mansion \& al. (p. 931) use ITS and plastid sequence data from the Mediterranean genus Centaurium to provide an evolutionary frame for their previous cytological and morphological studies. They discuss well-documented cases of polyploidy, some of them associated with reticulation, and confirm the overall significant contribution of polyploidy in the evolution of this genus. Oberprieler (p. 951) approaches the biogeography of the large circum-Mediterranean clade of Anthemideae by using a combination of a DIVA analysis and a molecular clock approach that is based on an ITS phylogeny. Inferred vicariance and dispersal events are related to available paleogeologic and paleoclimatic data for a thorough synthesis.

Three more papers deal with differentiation and speciation. Thompson $\&$ al. (p. 967) examine ecological differentiation in Mediterranean narrow endemic species by searching for general patterns as compared to widespread congeners, and by discussing the possible contribution of ecologically and geographically marginal populations to diversification in Cyclamen. On the basis of their ongoing studies on Mediterranean orchids, Cozzolino and Widmer (p. 977) question the role of pollination-orchid interactions in driving differentiation and speciation. They found that wide occurrence of $F_{1}$ hybrids among different species, facilitated by similar pollination syndromes, does not lead to viable hybrid lineages, possibly due to chromosomal differences. Although documenting reticulation is feasible using evidence from differently inherited molecular markers (Vriesendorp \& Bakker, 2005), southern European refugia seem to favour particularly complex evolutionary scenarios, as reported by
Albaladejo \& al. (p. 987) using nuclear and plastid sequence data from western Mediterranean species of Phlomis.

Finally, Stace (p. 999) calls attention to the drawbacks of using DNA sequence data alone for reconstructing plant evolution, particularly when polyploidy is involved, and accordingly recommends not relying solely on such data but maintaining other more traditional sources of evidence.

\section{LITERATURE CITED}

Bocquet, G., Widler, B. \& Kiefer, H. 1978. The Messinian Model, a new outlook for the floristics and systematics of the Mediterranean area. Candollea 33: 269-287.

Comes, H. P. 2004. The Mediterranean region-a hotspot for plant biogeographic research. New Phytol. 164: 11-14.

Greuter, W. 1994. Extinctions in Mediterranean areas. Phil. Trans. Roy. Soc. London, B 344: 41-46.

Hewitt, G. M. 1996. Some genetic consequences of ice ages, and their role in divergence and speciation. Biol. J. Linn. Soc. 58: 247-276.

Médail, F. \& Quézel, P. 1997. Hot-spots analysis for conservation of plant biodiversity in the Mediterranean Basin. Ann. Missouri Bot. Gard. 84: 112-127.

Peyron, O., Guiot, J., Cheddadi, R., Tarasov, P., Reille, M., de Beaulieu, J. L., Bottema, S. \& Andrieu, V. 1998. Climatic reconstruction in Europe for 18,000 years B.P. from pollen data. Quatern. Res. 49: 183-196.

Rögl, F. \& Steininger, F. F. 1984. Neogene Paratethys, Mediterranean and Indo-pacific Seaways. Pp. 171-200 in: Brenchley, P. (ed.), Fossils and Climate. John Wiley \& Sons, Chichester.

Stuessy, T. F. 2004. Biosystematics - alive and well! Taxon 53: $861-862$.

Suc, J. P. 1984. Origin and evolution of the Mediterranean vegetation and climate in Europe. Nature 307: 429-432.

Thompson, J. D. 2005. Plant Evolution in the Mediterranean. Oxford Univ. Press, Oxford.

Vriesendorp, B. \& Bakker, F. T. 2005. Reconstructing patterns of reticulate evolution in angiosperms: what can we do? Taxon 54: 593-604. 